\title{
Effect of estrogen on manganese-induced toxicity on embryonic astrocytes"
}

\author{
Tyler T. Huynh, Kimberly J. Baker, Harold L. Komiskey ${ }^{\#}$
}

Department of Biomedical Sciences, Philadelphia College of Osteopathic Medicine-GA Campus, Suwanee, USA

Email:

Received 15 August 2013; revised 15 September 2013; accepted 1 October 2013

Copyright (C) 2013 Tyler T. Huynh et al. This is an open access article distributed under the Creative Commons Attribution License, which permits unrestricted use, distribution, and reproduction in any medium, provided the original work is properly cited.

\begin{abstract}
Manganese (Mn) is a natural trace metal that is essential for many physiological functions in the human body. Astrocytes in the central nervous system are susceptible reservoirs for Mn accumulation. Estrogen, a steroidal hormone, has been shown to mitigate Mninduced toxicity in cultures of postnatal astrocytes. However, differences in expression/inducibility of glutamate transporters and glutamine synthetase, transmitters, and the natural gonadal steroids and their receptors are known to occur in astrocyte cultures derived from various stages of fetal and postnatal development. Cultures of embryonic (E18) hippocampal astrocytes were examined in this study for the ability of $17 \beta$-estradiol (E2) to protect them from Mn toxicity by up regulating gene expression of a glutamate transporter. Primary rat hippocampal astrocytes were pretreated with $\beta$-Estradiol (E2) in vitro and subsequently, Mn sulfate $\left(\mathrm{MnSO}_{4}\right)$. The amount of toxic damage to the astrocytes was measured by quantifying glial fibrillary acidic protein (GFAP) with a sandwiched Enzyme-Linked Immunosorbent Assay (ELISA). ELISA analysis indicated Mn exposure at $100 \mu \mathrm{M}$, $300 \mu \mathrm{M}$, or $600 \mu \mathrm{M}$ significantly increased GFAP levels. However, E2 concentrations at $10 \mathrm{nM}$ or $30 \mathrm{nM}$ significantly reduced Mn-induced GFAP concentrations at $100 \mu \mathrm{M}$. Cells pretreated with $10 \mathrm{nM}$ or 30 nM of E2 significantly lowered GFAP levels. The Water-Soluble Tetrazolium-8 (WST-8) method was utilized to determine cell viability. The WST-8 assay showed that Mn concentrations of $100 \mu \mathrm{M}, 300 \mu \mathrm{M}$, or 600 $\mu M$ significantly reduced the dehydrogenase activity, thereby decreasing the number of viable astrocytes. Enzyme activity with $600 \mu \mathrm{M}$ of Mn was significantly
\end{abstract}

\footnotetext{
"Acknowledgements: We thank CCDA and Philadelphia College of Osteopathic Medicine for funding.

${ }^{\#}$ Corresponding author.
}

decreased when compared with $100 \mu \mathrm{M}$ of $\mathrm{Mn}$, revealing a dose-dependent effect. However, the dehydrogenase activity in cells treated with $600 \mu M$ Mn was significantly increased when pretreated with 10 nM of E2. Reverse Transcriptase-Polymerase Chain Reaction (RT-PCR) was used to measure changes in glutamate transporter-1 gene expression in astrocytes after pretreatment of E2 and subsequently, Mn. PCR analysis showed that when cells were exposed to 300 $\mu \mathrm{M}$ Mn, the GLT-1 gene expression was reduced compared to the control. Data also showed that the GLT1 mRNA was upregulated in cells pretreated with 10 nM E2. When the cells were pretreated with $10 \mathrm{nM}$ E2 and subsequently, $300 \mu \mathrm{M} M n$, there was an increase in the GLT-1 gene expression. The experimental results indicate that E2 can attenuate some Mn-induced toxicity in E18 astrocytes.

Keywords: Astrocytes; Estrogen; Embryonic; Manganese; Hippocampus

\section{INTRODUCTION}

Astrocytes are brain cells believed to be adversely affected early by manganese (Mn) toxicity $[1,2]$. Although astrocytes perform numerous functions essential for brain activity, they accumulate up to 50 times higher $\mathrm{Mn}$ concentration compared to neurons $[3,4]$. The normal intracellular Mn concentrations are between 50 to $75 \mu \mathrm{M}$, serving as a cofactor for glutamine synthetase $[3,5]$. The buildup of excessive Mn within astrocytes is argued to mediate neurotoxicity by oxidative stress and diminishing glutamate transport $[6,7]$. In fact, $\mathrm{Mn}$ has been reported to down regulate gene expression of glutamate transporters [8]. Estrogen (E) receptor agonists have even been reported to protect astrocytes from Mn-provoked neurotoxicity by up regulating the gene expression of glutamate transporters [9-11]. In addition, Mn alters the glutamate- 
glutamine homeostasis $[12,13]$.

The above studies were conducted with postnatal astrocytes. However, differences in expression/inducibility of glutamate transporters and glutamine synthetase are known to occur in astrocyte cultures derived from various stages of fetal and postnatal development $[14,15]$. Differences exist in transmitter effects on embryonic and postnatal astrocytes $[16,17]$. In addition, the natural gonadal steroids and their receptors vary during fetal and postnatal development $[18,19]$. Cultures of embryonic (E18) hippocampal astrocytes were examined in this study for the ability of $17 \beta$-estradiol (E2) to protect them from $\mathrm{Mn}$ toxicity by up regulating gene expression of a glutamate transporter.

\section{MATERIALS AND METHODS}

\subsection{Cell Culture}

Primary Embryonic (day 18 Sprague/Dawley) rat hippocampal astrocytes obtained from Gelantis (San Diego, CA) were prepared using the NeuroPapain enzyme. Following enzymatic pretreatment, the supernatant (containing the NeuroPapain solution) was removed, and the astrocytes were placed in a $75 \mathrm{~cm}^{2}$ Poly-D-Lysine filter cap flask containing a complete media mixture of $34 \%$ Gibco DMEM High Glucose, 34\% HyClone DME/High Glucose (1X), 25\% HANKS, 3.5\% Gibco Dialyzed Fetal Bovine Serum, and 3.5\% HyClone Donor Equine Serum at $37^{\circ} \mathrm{C}$ with $5 \% \mathrm{CO}_{2}$.

\subsection{Trypsinization and Pretreatment}

Once cells reached $70 \%$ or greater confluence, $0.25 \%$ trypsin was used to remove them from the flask. After a wash with complete media, the astrocytes were transferred to a Poly-D-Lysine coated 48-well plate. The wells containing astrocytes and complete media mixture were treated with media or increasing concentrations of E2 on the same day. Twenty-four hours later, some of the wells were treated with increasing dosages of $\mathrm{MnSO}_{4}$.

\subsection{Bicinchoninic Acid (BCA) Assay}

Pierce BCA protein assay (Rockford, IL) was used to measure the level of total protein concentration present in the cell samples. The absorbance was read at $562 \mathrm{~nm}$.

\subsection{Cell Viability Assay}

Cell viability was determined by measuring a water soluble formazan after the addition of highly water soluble tetrazolium salts called WST-8. Cell Counting Kit-8 (CCK-8, Sigma Chemical) used WST-8 to measure the dehydrogenase enzyme activity inside the cell to analyze the viability of the astrocytes. The absorbance was read at $450 \mathrm{~nm}$.

\subsection{Enzyme-Linked Immunosorbent Assay (ELISA)}

The amount of toxicity damage to the astrocytes was measured by quantifying GFAP in a sandwiched ELISA, according to O'Callaghan [20]. A 96-well microtiter plate was coated with $100 \mu \mathrm{l}$ of polyclonal rabbit anti-cow GFAP antibody, then incubated for $1 \mathrm{hr}$ at $37^{\circ} \mathrm{C}$ with $5 \%$ $\mathrm{CO}_{2}$ and overnight at $4^{\circ} \mathrm{C}$ in the refrigerator. The polyclonal anti-GFAP solution was washed with $200 \mu \mathrm{l}$ of PBS four times. Next, $100 \mu l$ of BLOTTO (Bovine Lacto Transfer Technique Optimizer) was added and incubated for $1 \mathrm{hr}$. BLOTTO was removed and the purified GFAP standards and cell samples were loaded. The plate was washed four times with PBS and $0.5 \%$ Triton X-100 combination. A solution of monoclonal anti-GFAP mouse antibody was mixed with BLOTTO and $0.5 \%$ Triton X100 to be loaded and incubated for $1 \mathrm{hr}$ at room temperature. Again, the plate was washed four times with the PBS and $0.5 \%$ Triton X-100 mixture. Alkaline Phosphatase-Conjugated anti-mouse $\operatorname{IgG}$ was mixed with BLOTTO and $0.5 \%$ Triton X-100, added, and incubated for $30 \mathrm{mins}$ at room temperature. The plate was washed four times with the PBS and 0.5\% Triton X-100 mixture. P-Nitrophenyl Phosphate Liquid Substrate was added to the plate and incubated for $25 \mathrm{~min}$ at room temperature. Finally, $0.4 \mathrm{~N} \mathrm{NaOH}$ was used to stop the reaction and the absorbance values were read at $405 \mathrm{~nm}$.

\subsection{Reverse Transcriptase-Polymerase Chain Reaction (RT-PCR)}

RT-PCR was used to measure Glutamate Transporter-1 gene expressions by detecting the levels of RNA in astrocytes. Each sample was normalized to Glyceraldehyde 3phosphate dehydrogenase (GAPDH) [21]. RNeasy Mini Kit from Qiagen was used to extract RNA from the astrocytes by following the manufacture's protocol. A High-Capacity cDNA Reverse Transcription Kit (Life Technologies) was used to transcribe the RNA into a cDNA by following the manufacturer's protocol. The first cycle was ran for $10 \mathrm{~min}$ at $25^{\circ} \mathrm{C}$, then $120 \mathrm{~min}$ at $37^{\circ} \mathrm{C}$, and finally, for $5 \mathrm{~min}$ at $85^{\circ} \mathrm{C}$. PCR was carried out using a Platinum PCR SuperMix (Life Technologies) by following the manufacturer's protocol also. Primer sequences were: 5'-CCT CAT GAG GAT GCT GAA GA-3' (GLT-1 forward), 5'-TCC AGG AAG GCA TCC AGG CTG-3' (GLT-1 reverse), 5'-TCC CTC AAG ATT GTC AGC AA-3' (GAPDH forward), and 5'-AGA TCC ACA ACG GAT ACA TT-3' (GAPDH reverse). Each primer was diluted to $0.2 \mu \mathrm{M}$ with RNase-free water according to the Certificate of Analysis. Then, the mixture was added to $45 \mu \mathrm{l}$ of PCR SuperMix to make up a total reaction volume of $50 \mu$ l. Amplification was performed with $30 \mathrm{cy}-$ cles at $94^{\circ} \mathrm{C}$ for $30 \mathrm{~s}$ (denaturation), $55^{\circ} \mathrm{C}$ for $30 \mathrm{~s}$ (an- 
neal), and $72^{\circ} \mathrm{C}$ for 1 min (extension). The samples were analyzed on a $1.5 \%$ agarose gel electrophoresis and visualized by using GelRed Nucleic Acid Stain.

\subsection{Statistical Analysis}

Data was analyzed using One-way Analysis of Variance (ANOVA) using GraphPad Prism 5 Software with Duncan's new multiple range test [22]. P-values less than 0.05 were considered significant. The number of primer sequence base pairs used in RT-PCR was analyzed from National Center for Biotechnology Information (NCBI) online@ http://www.ncbi.nlm.nih.gov/. The average pixel density (APD) of the agarose gel images was analyzed using Image J64 to calculate the GLT-1/GAPDH percentiles.

\section{RESULTS}

\subsection{E2 Decreases GFAP Levels}

To determine the neuroprotective effects of E2, cells were pretreated with E2 for 72 hrs. The ELISA showed that astrocytes pretreated with E2 at $10 \mathrm{nM}(\mathrm{p}<0.05)$ or $30 \mathrm{nM}(\mathrm{p}<0.05)$ significantly lowered GFAP levels when compared with the control (Figure 1).

\subsection{GFAP Levels Compared in Cells Treated with Mn and Cells with E2 and Mn}

To determine Mn's toxic effect in astrocytes, the cells were treated with $\mathrm{Mn}$ for $48 \mathrm{hrs}$. The ELISA results showed that Mn significantly increased GFAP production $(100 \mu \mathrm{M}$, $\mathrm{p}<0.05 ; 300 \mu \mathrm{M}, \mathrm{p}<0.05 ; 600 \mu \mathrm{M}, \mathrm{p}<0.05)$ when compared to the control (Figure 2). Results also showed cells pretreated with $10 \mathrm{nM}(\mathrm{p}<0.01)$ or $30 \mathrm{nM}(\mathrm{p}<0.01)$ of E2 significantly lowered Mn-induced GFAP level at $100 \mu \mathrm{M}$ (Figure 2).

\subsection{E2 Effect on Dehydrogenase Activity}

Although not statistically significant, the WST-8 assay showed cells pretreated with E2 had a trend of increasing dehydrogenase activity starting at $10 \mathrm{nM}$ (Figure 3).

\subsection{Dehydrogenase Activity Compared in Cells Treated with Mn and Cells Treated with E2 and Mn}

The WST-8 assay showed that Mn significantly reduces the activity of dehydrogenase enzyme at $100 \mu \mathrm{M}(\mathrm{p}<$ $0.01), 300 \mu \mathrm{M}(\mathrm{p}<0.01)$, or $600 \mu \mathrm{M}(\mathrm{p}<0.01)$ (Figure 4). Data also show that the control is significantly different from all treatment groups $(p<0.01)$ (Figure 4). The dehydrogenase activity in cells treated with $600 \mu \mathrm{M} \mathrm{Mn}$ was significantly increased when pretreated with $10 \mathrm{nM}$ E2 $(\mathrm{p}<0.05)$ (Figure 4). Enzyme activity with 600

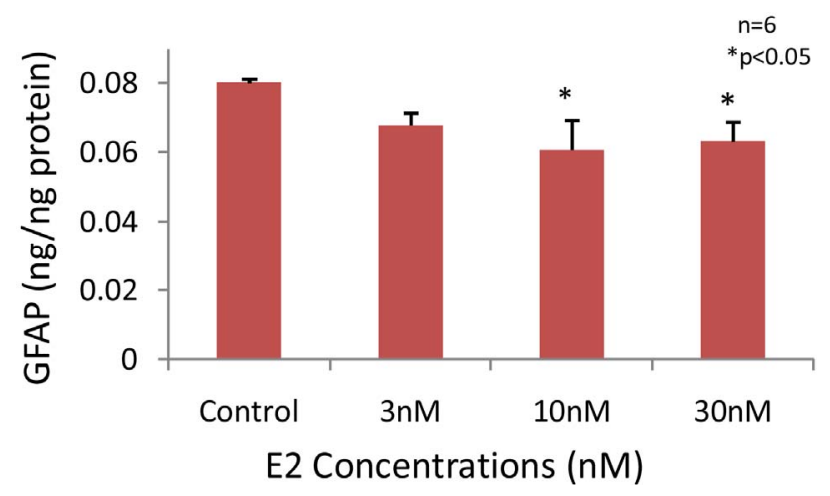

Figure 1. E2 effect on GFAP level using ELISA. Cells pretreated with E2 at $10 \mathrm{nM}(\mathrm{p}<0.05)$ or $30 \mathrm{nM}(\mathrm{p}<0.05)$ significantly lowered GFAP levels when compared with the control $(n=6)$.

$\mu \mathrm{M}$ Mn was significantly decreased when compared with $100 \mu \mathrm{M}$ Mn $(\mathrm{p}<0.05)$, revealing a dose-dependent effect (Figure 4).

\subsection{RT-PCR Results for Cells Treated with $\mathbf{1 0}$ nM E2 and Cells with 10 nM E2 and 300 $\boldsymbol{\mu M}$ Mn}

Gel electrophoresis and NCBI analysis showed PCR amplified a portion of the GLT-1 gene that was 217 base pairs and 268 base pairs of the GAPDH gene (Figure 5(a)). Although not statistically significant $(n=2)$, results showed an increased expression of GLT-1 mRNA by $17 \%$ when cells were pretreated with 10 nM E2 (Figure 5(b)). When cells were pretreated with $10 \mathrm{nM}$ E2 and afterward, exposed to $300 \mu \mathrm{M} \mathrm{Mn}$, there was an increased production of the GLT-1 gene expression by 12\% (Figure 5(b)).

\section{DISCUSSION}

The present study demonstrates that acute exposure to E2 can mitigate some Mn-induced toxicity in E18 astrocytes concerning inflammation, cell viability, and glutamate transport system. Mn was shown to induce toxicity and upregulate inflammation in astrocytes by significantly increasing GFAP production at $100 \mu \mathrm{M}, 300 \mu \mathrm{M}$, or 600 $\mu \mathrm{M}$ (Figure 2). Although not statistically significant, the GFAP levels trended to increase with the Mn concentration. However, E2 concentrations at $10 \mathrm{nM}$ or $30 \mathrm{nM}$ significantly decreased Mn-induced GFAP concentrations at $100 \mu \mathrm{M}$ (Figure 2). In addition, E2 pretreated cells at 10 $\mathrm{nM}$ or $30 \mathrm{nM}$ significantly lowered GFAP levels compared to the control (Figure 1). E2 could be reversing or inhibiting the Mn-induced GFAP level. Rozovsky et al. [23] demonstrated the attenuation of GFAP via E2 in cortex astrocytes ( 1 - 3 day old) from ovariectomized female rats 3 months old. It was also shown that the interaction of $\mathrm{ER} \alpha$ and estrogen response element (ERE) were involved 


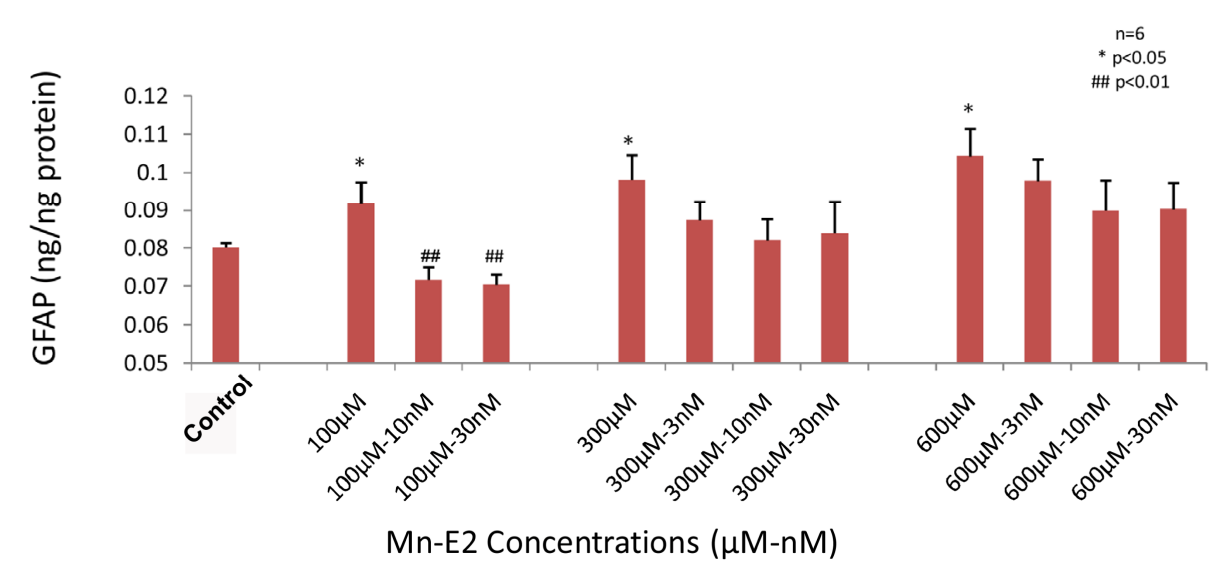

Figure 2. GFAP levels compared in cells treated with Mn and cells treated with E2 and Mn. Mn was shown to significantly increase GFAP levels at $100 \mu \mathrm{M}(\mathrm{p}<0.05), 300 \mu \mathrm{M}(\mathrm{p}<0.05)$, or $600 \mu \mathrm{M}(\mathrm{p}<0.05)$ when compared to the control $(\mathrm{n}=6)$. However, cells pretreated with 10 $\mathrm{nM}(\mathrm{p}<0.01)$ or $30 \mathrm{nM}(\mathrm{p}<0.01)$ of E2 significantly lowered Mn-induced GFAP level at 100 $\mu \mathrm{M}(\mathrm{n}=6)$.

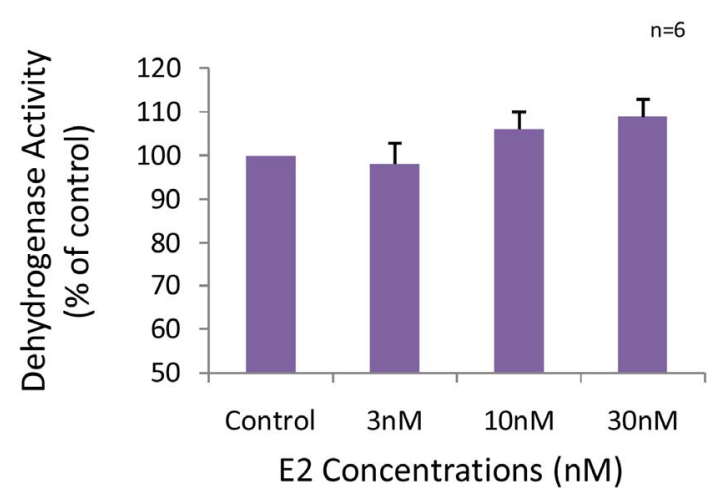

Figure 3. E2 effect on dehydrogenase activity using the WST-8 assay Dehydrogenase activity in cells. Cells pretreated with E2 were not statistically significant, but did show a tendency of increasing activity with 10 $\mathrm{nM}$ and $30 \mathrm{nM}(\mathrm{n}=6)$.

in the gene expression of GFAP [23].

Cell viability depends on many chemicals and enzymes working together to ensure that biochemical reactions properly take place. Dehydrogenase enzyme is one that catalyzes the transfer of a hydride ion to nicotinamide adenine dinucleotide (NAD) or nicotinamide adenine dinucleotide phosphate (NADP) in the mitochondria. These reactions are particularly important in glycolysis, citric acid cycle, and electron transport chain. Therefore, to determine the level of dehydrogenase activity would reveal the cell's viability [24]. The WST-8 assay established that all treatment groups pretreated with E2 and/or exposed to Mn significantly affected the dehydrogenase activity in astrocytes when compared to the control (Figure 4). This could be due to the age of astrocytes employed; embryonic astrocytes could be especially sensitive to chemical agents, thus greatly affecting their cell viability [25]. Mn was shown to significantly reduce the enzyme's activity at $100 \mu \mathrm{M}, 300 \mu \mathrm{M}$, or $600 \mu \mathrm{M}$, thereby, significantly decreasing the number of viable astrocytes (Figure 4). Once excess $\mathrm{Mn}$ has been sequestered in the mitochondria, it could generate reactive oxygen species (ROS) generation, oxidative stress, and ultimately, apoptosis. Pretreatment of E2 at $10 \mathrm{nM}$ was shown to significantly attenuate Mn-induced decrease in dehydrogenase activity at $600 \mu \mathrm{M}$ (Figure 4). E2 was able to inhibit ROS and oxidative stress formation stimulated by Mn. Astrocyte protection afforded by E2 was most likely mediated through the activation of $\mathrm{PI}_{3} \mathrm{~K} / \mathrm{PKB} / \mathrm{Akt}$ and MAPK signaling pathways. Both pathways are extensively involved in Mn-induced cell death and neuroprotective effects of E2 [21,26]. Lee et al. (2009) conducted a similar experiment where they demonstrated Mn-induced cell death in neonatal rat primary astrocytes by generation of ROS [27]. The WST-8 assay showed cells pretreated with E2 had a non-significant increase in dehydrogenase activity starting at $10 \mathrm{nM}$ (Figure 3). Also, Mn produces a dose-dependent effect when the dehydrogenase activity was significantly decreased at exposure to $600 \mu \mathrm{M}$ vs. $100 \mu \mathrm{M}$ (Figure 4). This result leads to the notion that the magnitude of adverse biological response in astrocytes caused by $\mathrm{Mn}$ is dependent on its concentration.

Researchers have previously shown that E2 can increase the GLT-1 gene expression in cultures with rat neonatal midbrain and cortical astrocytes [27,28]. One of the experimental aims was to examine if the outcome would be similar in rat embryonic hippocampal astrocytes. PCR analysis did show that the GLT-1 gene expression was upregulated in cells pretreated with $10 \mathrm{nM}$ E2 (Figure 5(b)). Due to the fact that an antagonist is not present, this could suggest that there was a slow genomic mechanism with $\mathrm{E} 2$ binding to either $\mathrm{ER} \alpha$ or $\beta$ in the nu- 


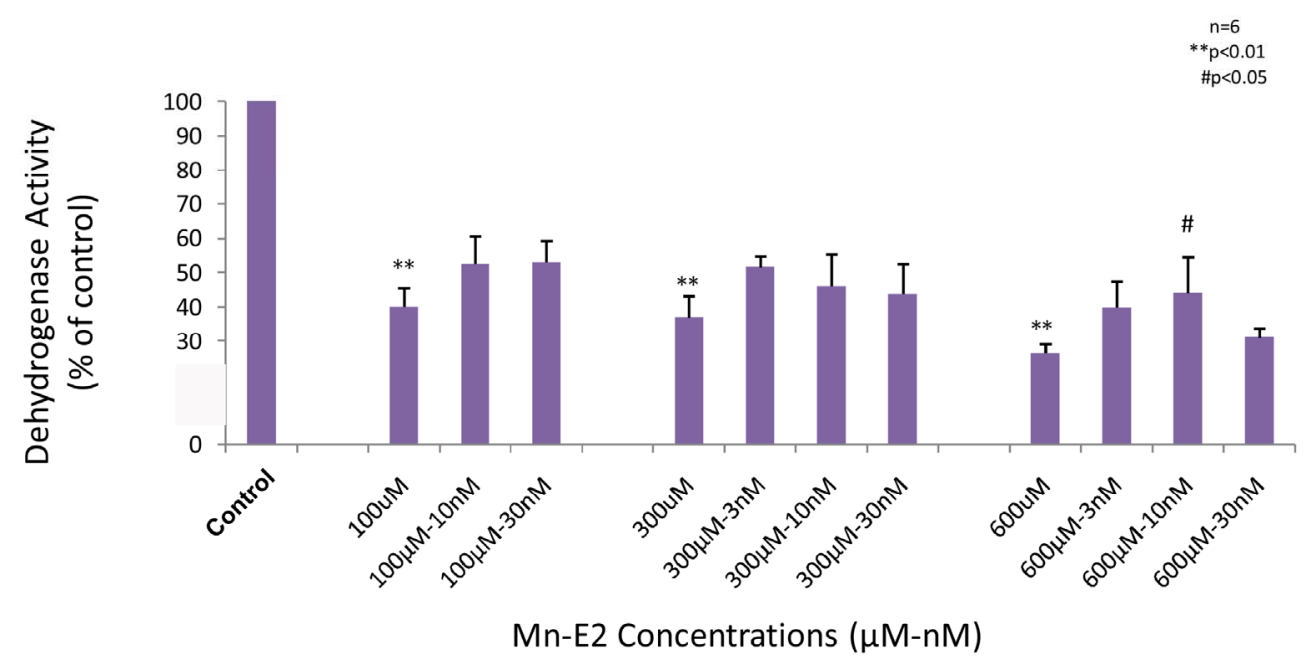

Figure 4. Dehydrogenase activity compared in cells treated with Mn and cells treated with E2 and Mn using WST-8 assay. Mn was shown to significantly reduce the enzyme's activity at $100 \mu \mathrm{M}(\mathrm{p}<0.01)$, $300 \mu \mathrm{M}(\mathrm{p}<0.01)$, or $600 \mu \mathrm{M}(\mathrm{p}<0.01)$, thereby, significantly decreasing the number of viable astrocytes $(\mathrm{n}=6)$. The control group was shown to be significantly different from all treatment groups $(\mathrm{p}$ $<0.01)(\mathrm{n}=6)$. Pretreatment of E2 at $10 \mathrm{nM}$ was shown to significantly decrease Mn-induced dehydrogenase activity at $600 \mu \mathrm{M}(\mathrm{n}=6)$. Mn produced a dose-dependent effect when the dehydrogenase activity was significantly decreased at exposure to $600 \mu \mathrm{M}$ vs. $100 \mu \mathrm{M}(\mathrm{n}=6)$.

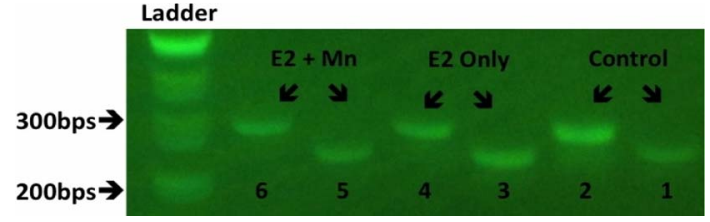

(a)

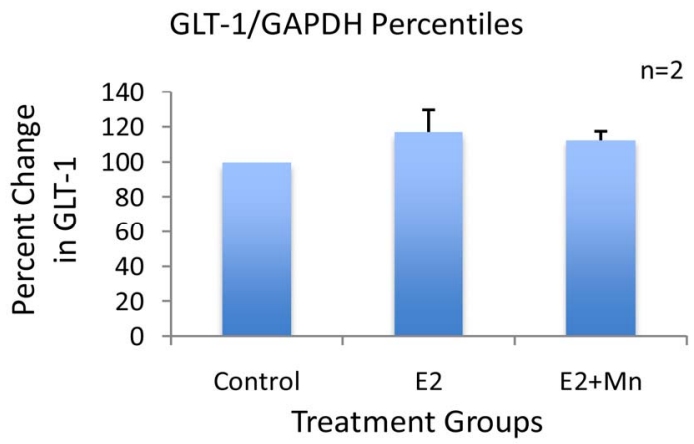

(b)

Figure 5. GLT-1 levels in cells pretreated with $10 \mathrm{nM}$ E2 compared with cells pretreated with $10 \mathrm{nM}$ E2 and subsequently exposed to $300 \mu \mathrm{M} \mathrm{Mn}$. Lanes 1,3 , and 5 contain GLT-1 gene. Lanes 2, 4, and 6 contain GAPDH gene. PCR amplified a section of the GLT-1 gene that was $217 \mathrm{bp}$ and $268 \mathrm{bp}$ of the GAPDH gene. (a): Image J64 analysis showed pretreatment of E2 alone increased GLT-1 mRNA level by $17 \%$; (b): When cells were pretreated with $10 \mathrm{nM} \mathrm{E2}$ and afterward, exposed to 300 $\mu \mathrm{M} \mathrm{Mn}$, there was an increased production of the GLT1 gene expression by $12 \%$.

cleus to activate ERE and acquire transcription of the GLT-1 gene. Another genomic possibility is via GPER and CRE transcription mechanisms [29]. To determine which ER contributes to the increased GLT-1 gene, experiments pertaining to the silencing of ERs by siRNA transfection could be carried out. For example, a knockdown of the GPER and then, treating astrocytes in culture with G-1, a GPER agonist, could explain the role GPER plays. Through the process of elimination, it could deduce which ER is solely responsible or perhaps, it is the combination of 1 - 3 ERs [21].

However, with the upregulation of GLT-1 with $10 \mathrm{nM}$ E2 and $300 \mu \mathrm{M}$ Mn together (Figure 5(b)), there may be a more rapid mechanism to reverse $\mathrm{Mn}$-induced decrease in the GLT-1 mRNA. It has been suggested that transforming growth factor- $\alpha$ (TGF- $\alpha)$ and multiple signaling pathways, which can include $\mathrm{PI}_{3} \mathrm{~K}, \mathrm{MAPK}, \mathrm{EGFR}$, and PKA, mediate the protective effects of E2 on Mn-induced glutamate transport systems. The possibility that E2 could be activating multiple signaling pathways simultaneously to ensure cell proliferation and survival should be considered strongly. TGF- $\alpha$, which mainly acts on astrocytes and is upregulated by E2, is possibly a major component in the protection against the downregulation of GLT-1 gene expression. TGF- $\alpha$ would bind to its receptor, EGFR, to activate the $\mathrm{PI}_{3} \mathrm{~K}$ and MAPK signaling cascades, which would reverse or protect $\mathrm{Mn}$-induced effect on GLT-1 proteins [30]. The notion that E2 could be mediating genomic effects in addition to non-genomic is also likely. When the cells were pretreated with E2 and Mn, E2 not only compensated for the loss of GLT-1 mRNA caused by Mn, but it could have "overcorrected" the situation. It was observed that there was about a $12 \%$ 
increase in the gene expression compared to the control group (Figure 5(b)). This protective mechanism against Mn would ensure increased glutamate uptake from the synaptic cleft and prevent neuroexcitation.

The above evidence supports the hypothesis that E2 can attenuate some Mn-induced toxicity in E18 astrocytes. The study revealed Mn's degree of neurotoxic effects on astrocytes with varying concentrations. Mn level can exceed $350 \mu \mathrm{M}$ in the brain during toxicity, but this study indicates a concentration starting at $100 \mu \mathrm{M}$ can become dangerous for astrocytes [31]. This finding is pertinent to the growing concern of the association between deleterious effects of excess $\mathrm{Mn}$ on astrocytes and developmental neurotoxicology. The Mn-induced levels of GFAP, dehydrogenase activity, and GLT-1 could be the bridge that connects this association. The results of this study indicate that E2 can shield rat fetal astrocytes from some of the cellular damage brought upon by Mn from day 18 on, but the vulnerability of younger fetal astrocytes to $\mathrm{Mn}$ and possible E2 protection are unknown.

\section{REFERENCES}

[1] Henriksson, J. and Tjalve, H. (2000) Manganese taken up into the CNS via the olfactory pathway in rats affects astrocytes. Toxicological Sciences, 55, 392-398. http://dx.doi.org/10.1093/toxsci/55.2.392

[2] Sidoryk-Wegrzynowicz, M. and Aschner, M. (2013) Role of astrocytes in manganese mediated neurotoxicity. $B M C$ Pharmacology and Toxicology, 14, 1-10.

[3] Aschner, M., Gannon, M. and Kimelberg, H.K. (1992) Manganese uptake and efflux in cultured rat astrocytes. Journal Neurochemistry, 58, 730-735. http://dx.doi.org/10.1111/j.1471-4159.1992.tb09778.x

[4] Aschner, M., Guilarte, T.R., Schneider, J.S. and Zheng, W. (2007) Manganese: Recent advances in understanding its transport and neurotoxicity. Toxicology Applied Pharmacology, 221, 131-147. http://dx.doi.org/10.1016/j.taap.2007.03.001

[5] Gorovits, R., Avidan, N., Avisar, N., Shaked, I. and Vardimon, L. (1997) Glutamine synthetase protects against neuronal degeneration in injured retinal tissue. Proceedings National Academy Science USA, 94, 7024-7029. http://dx.doi.org/10.1073/pnas.94.13.7024

[6] Erikson, K. and Aschner, M. (2002) Manganese causes differential regulation of glutamate transporter (GLAST) taurine transporter and metallothionein in cultured rat astrocytes. Neurotoxicology, 23, 595-602. http://dx.doi.org/10.1016/S0161-813X(02)00012-8

[7] Desole, M.S., Sciola, L., Delogu, M.R., Sircana, S., Migheli, R. and Miele, E. (1997) Role of oxidative stress in the manganese and 1-methyl-4-(2'-ethylphenyl)-1,2,3,5tetrahydropyridine-induced apoptosis in PC12 cells. Neurochemistry International, 31, 169-176. http://dx.doi.org/10.1016/S0197-0186(96)00146-5

[8] Sidoryk-Wegrzynowicz, M., Lee E., Albrecht, J. and As- chner, M. (2009) Manganese disrupts astrocyte glutamine transporter expression and function. Journal Neurochemistry, 110, 822-830. http://dx.doi.org/10.1111/j.1471-4159.2009.06172.x

[9] Deng, Y., Xu, Z., Xu, B., Xu, D., Tian, Y. and Feng, W. (2012) The protective effects of riluzole on manganeseinduced disruption of glutamate transporters and glutamine synthetase in the cultured astrocytes. Biological Trace Element Research, 148, 242-249. http://dx.doi.org/10.1007/s12011-012-9365-1

[10] Lee, E.S., Sidoryk, M., Jiang, H., Yin, Z. and Aschner, M. (2009) Estrogen and tamoxifen reverse manganese-induced glutamate transporter impairment in astrocytes. Journal Neurochemistry, 110, 530-544. http://dx.doi.org/10.1111/j.1471-4159.2009.06105.x

[11] Lee, E., Yin, Z., Milatovic, D., Jiang, H. and Aschner, M. (2009). Estrogen and tamoxifen protect against Mn-induced toxicity in rat cortical primary cultures of neurons and astrocytes. Toxicological Sciences, 110, 156-167. http://dx.doi.org/10.1093/toxsci/kfp081

[12] Zwingmann, C., Leibfritz, D. and Hazell, A.S. (2003) Energy metabolism in astrocytes and neurons treated with manganese: Relation among cell-specific energy failure, glucose metabolism, and intercellular trafficking using multinuclear NMR-spectroscopic analysis. Journal of Cerebral Blood Flow and Metabolism, 23, 756-771.

[13] Erikson, K.M., Dorman, D.C., Lash, L.H. and Aschner, M. (2007) Manganese inhalation by rhesus monkeys are associated with brain regional changes in biomarkers of neurotoxicity. Toxicological Sciences, 97, 459-466. http://dx.doi.org/10.1093/toxsci/kfm044

[14] Hertz, L., Bock, E. and Schousboe, A. (1978) GFA content, glutamate uptake and activity of glutamate metabolizing enzymes in differentiating mouse astrocytes in primary cultures. Developmental Neuroscience, 1, 226-238. http://dx.doi.org/10.1159/000112577

[15] Stanimirovic, D.B., Ball, R., Small, D.L. and Muruganandam, A. (1999) Developmental regulation of glutamate transporters and glutamine synthetase activity in astrocyte cultures differentiated in vitro. International Journal of Developmental Neuroscience, 17, 173-184. http://dx.doi.org/10.1016/S0736-5748(99)00028-3

[16] Abe, K. and Saito, H. (1999) Effect of ATP on astrocyte stellation is switched from suppressive to stimulatory during development. Brain Research, 850, 150-157. http://dx.doi.org/10.1016/S0006-8993(99)02121-6

[17] Abe, K. and Saito, H. (1997) Developmental changes in cyclic AMP-stimulated stellation of cultured rat cortical astrocytes. Japanese Journal Pharmacology, 75, 433-438. http://dx.doi.org/10.1254/jijp.75.433

[18] Quadros, P.S., Pfau, J.L., Goldstein, A.Y.N., De Vries, G.J. and Wagner, C.K. (2002) Sex differences in progesterone receptor expression: A potential mechanism for estradiol-mediated sexual differentiation. Endocrinology, 143, 3727-3739. http://dx.doi.org/10.1210/en.2002-211438

[19] Quadros, P.S., Pfau, J.L. and Wagner, C.K. (2007) Distribution of progesterone receptor immunoreactivity in the fetal and neonatal rat forebrain. The Journal of Compara- 
tive Neurology, 504, 42-56. http://dx.doi.org/10.1002/cne.21427

[20] O'Callaghan, J.P. (1993) Quantitative features of reactive gliosis following toxicant-induced damage of the CNS. In: Johannessen, J.N., Ed., Markers of Neuronal Injury and Degeneration, Academic Science, 679, 195-210.

[21] Lee, E., Sidoryk-Wegrzynowicz, M., Wang, N., Webb, A., Son, D., Lee, K. and Aschner, M. (2012) GPR30 regulates glutamate transporter GLT-1 expression in rat primary astrocytes. Journal of Biological Chemistry, 287, 2681726828. http://dx.doi.org/10.1074/jbc.M112.341867

[22] Steel, R.G.D. and Torrie, J.H. (1960) Principles and procedures of statistics. McGraw, New York.

[23] Rozovsky, I., Wei, M., Stone, D.J., Zanjani, H., Anderson, C.P., Morgan, T.E. and Finch, C.E. (2002) Estradiol (E2) enhances neurite outgrowth by repressing glial fibrillary acidic protein expression and reorganizing laminin. Endocrinology, 143, 636-646. http://dx.doi.org/10.1210/en.143.2.636

[24] Nelson, D.L. and Cox, M.M. (2008) Principles of Biochemistry, 5th Edition, W H. Freeman and Company, New York.

[25] Powers, C.M., Bale, A.S., Kraft, A.D., Makris, S.L., Trecki, J., Cowden, J., Hotchkiss, A. and Gillespie, P.A. (2013) Developmental neurotoxicity of engineered nanomaterials: Identifying research needs to support human health risk assessment. Toxicological Sciences, 134, 1-10. http://dx.doi.org/10.1093/toxsci/kft109

[26] Alaimo, A., Gorojod, R.M. and Kotler, M.L. (2011) The extrinsic and intrinsic apoptotic pathways are involved in manganese toxicity in rat astrocytoma C6 cells. Neurochemistry International, 59, 297-308.

http://dx.doi.org/10.1016/i.neuint.2011.06.001

[27] Lee, E., Yin, Z., Milatovic, D., Jiang, H. and Aschner, M. (2009) Estrogen and tamoxifen protect against Mn-induced toxicity in rat cortical primary cultures of neurons and astrocytes. Toxicological Sciences, 110, 156-167. http://dx.doi.org/10.1093/toxsci/kfp081

[28] Pawlak, J., Brito, Kuppers, E. and Beyer, C. (2005) Regulation of glutamate transporter GLAST and GLT-1 expression in astrocytes by estrogen. Molecular Brain Research, 138, 1-7. http://dx.doi.org/10.1016/j.molbrainres.2004.10.043

[29] Novella, S., Dantas, A.P., Segarra, G. Medina, P. and Hermenegildo, C. (2012) Vascular aging in women: Is estrogen the fountain of youth? Frontiers in Physiology, 3, 18. http://dx.doi.org/10.3389/fphys.2012.00165

[30] Lee, E., Sidoryk-Wegrzynowicz, M., Yin, Z., Webb, A., Son, D. and Aschner, M. (2012) Transforming growth factor- $\alpha$ mediates estrogen-induced upregulation of glutamate transporter GLT-1 in rat primary astrocytes. Glia, 60, 1024-1036. http://dx.doi.org/10.1002/glia.22329

[31] Erikson, K. and Aschner, M. (2002) Manganese causes differential regulation of glutamate transporter (GLAST) taurine transporter and metallothionein in cultured rat astrocytes. Neurotoxicology, 23, 595-602. http://dx.doi.org/10.1016/S0161-813X(02)00012-8 